\title{
The Effect of Stimulation, Detection, and Early Intervention Development Training Based on Group Dynamics on Motivation and Skill among Cadre
}

\author{
Tria Puspita Sari, Rusiana Sri Haryanti \\ School of Health Sciences PKU Muhammadiyah, Surakarta
}

\begin{abstract}
Background: Early childhood development monitoring by cadre was an effort to detect delayed development among children. Knowledge of child growth and development was highlighted as important for all cadres. Based on the survey in Surakarta, Central Java, in 2017, many cadres did not know about stimulation detection and early interventions development (SDEID). The purpose of this study was to analyze the effect of SDEID training based on group dynamics on cadre's motivation and skill.

Subjects and Method: This study was a quasy experiment conducted in Kadipiro, Surakarta, Central Java, from February to September 2018. A sample of 21 cadres was selected for this study by total sampling. The dependent variable was motivation and skill. The independent variables were SDEID training. The data were collected by questionnaire and analyzed by paired t-test.

Results: There was no difference motivation before $($ mean $=64.62$; $\mathrm{SD}=4.95)$ and after $(\mathrm{mean}=$ 63.62; $\mathrm{SD}=5.17)$ training, but it was statistically non-significant $(\mathrm{p}=0.526)$. Cadre's skill after $($ mean $=29.71 ; \mathrm{SD}=6.52)$ was higher than before training $($ mean $=11.00 ; \mathrm{SD}=5.24)$ and it was statistically significant $(\mathrm{p}<0.001)$.
\end{abstract}

Conclusion: SDEID training based on group dynamics is effective to improve cadre's skill.

Keywords: SDEID training, group dynamics, motivation, skill, cadres

\section{Correspondence:}

Rusiana Sri Haryanti. Jl. Tulang Bawang Selatan No. 26, Kadipiro, Banjarsari, Surakarta, Central Java. Mobile: 085702162126, 082225297203. Email: triapipit20@gmail.com, rusianamolyn@gmail.com.

\section{BACKGROUND}

The growth and development of toddlers occur very quickly as a foundation for the next development that determines the future of the child. One indicator of a quality child is a period of optimal growth and development. Achieving optimal growth and development of children is the result of the interaction of various interrelated factors, namely genetic factors, environment, behavior, stimulation or stimulation that is useful. The stages of child development during the golden period require stimulation to increase children's potential development. The first year is a period of time that is very important for physical growth and development, the development of intelligence, abilities, motor and social emotional, which determines the future of the child. An important period in child development is childhood. In children, the development of language skills, creativity, social awareness, emotional and intelligence runs very fast and is the basis of the next development. Problems that often arise in children's growth and development include disorders of physical growth, motor development, language, emotions, and behavior. During this critical period, stimulation is needed so that the potential can be developed (Rosita and Norazizah, 2015).

Children under the age of five years old are the next generation of the nation so 
the quality of toddler growth needs serious attention. Toddlers need to get good nutrition, adequate stimulation and affordable by quality health services including detection and early intervention of growth deviation (Health Department, 2010).

The stages of development have a critical period that requires stimulation that is useful so that potential can develop and it needs attention. Toddler is a period that is very sensitive to the environment and this period lasts very short and cannot be repeated, so the toddler's period is called the "golden period" (window of opportunity) and "critical period" ( critical period). Any abnormality/slightest which was not detected especially not handled properly will reduce the quality of human resources in the future. Approximately $16 \%$ of toddlers experience neurological and brain development problems ranging from mild to severe, every two days, 1,00o babies experience motor development disorders and 3 to 6 of 1,00o babies also experience hearing loss and one in 100 children has less intelligence and speech delay (Ministry of Health, 2010).

Posyandu as a form of community participation in activities under the Ministry of Health is one of the most basic levels of public health education and monitoring. Child health can be identified early by detection. Detection that has been known to have a child's developmental dysfunction must be stimulated so that it does not get worse. Monitoring and detection of early childhood development is part of the tasks of Posyandu cadres in their respective working areas. The task of cadres becomes very important and complex because the problem of child development is not only directed at growth and physical development, but also the psychological development of toddlers (Sianturi, Tambunan, and Ningsih 2013). Harisman (2012) in
Zainiah (2014) states that the lack of training and coaching to improve adequate skills for cadres lead to a lack of understanding of cadre tasks.

Based on a survey conducted by researchers in several Posyandu in the Surakarta area, many posyandu cadres did not understand the Stimulation detection and early interventions development (SDEID), how to assess and observe toddler growth and development with SDEID assessment. Some cadres only understand about growth monitoring about how to fill in the height and weight charts in the KMS book. Considering the importance of the posyandu cadre's task in monitoring children's growth and development through early detection and stimulation of growth and development, the understanding and skills of each cadre in the concept of growth and development, early detection and stimulation of growth and development is highly required for cadres to detect toddler and preschool children growth (Primary Data of Gambirsari Community Health Center, 2018).

The purpose of the study was to analyze the effect of detection stimulation training and early growth and development interventions based on group dynamics on the motivation and skills of posyandu cadres. With the motivation and skills of Posyandu cadres who are trained on SDEID, they are expected to be able to support the efforts to monitor health and control the disruption of child development.

\footnotetext{
SUBJECTS AND METHOD

1. Study Design

This was a quasi experiment conducted in Kadipiro posyandu, Surakarta, Central Java, from February to September 2018.
} 


\section{Population and Sample}

The population of this study was all cadres in integrated health post (posyandu) in Surakarta, Central Java. A sample of 21 cadres was selected by total sampling.

\section{Data Collection}

The data were collected by questionnaire. Motivation was measured by using 20 questions in the questionnaire. Skills of cadres were measured by using 19 question items that referred to the SDEID assessment guidelines.

\section{Data Analysis}

The data were analyzed by paired t test.

\section{Research Ethics}

This research has obtained permission from the medical research ethics committee of the medical faculty of the University of Muhammadiyah Surakarta No: 1181 / B.2 / KEPK-FKUMS/IV/2018.

\section{RESULTS}

\section{Univariate Analysis}

Based on Table 1, it was known that the age of cadres was mostly between 47-54 years old (29\%). As many as 12 cadres (57\%) had education senior high school. As manya as 17 cadres $(81 \%)$ worked as housewife. The longer tenure was $\geq 5$ years (86\%).

\section{a. Sample Characteristics}

Table 1. Frequency distribution of posyandu cadre characteristics

\begin{tabular}{lcc}
\hline \multicolumn{1}{c}{ Characteristics } & N & \% \\
\hline Age & 2 & 10 \\
23-30 years old & 3 & 14 \\
31-38 years old & 5 & 24 \\
39-46 years old & 6 & 29 \\
47-54 years old & 3 & 14 \\
$55-62$ years old & 2 & 10 \\
> 62 years old & & \\
Education & 2 & 10 \\
Elementary school & 3 & 14 \\
Junior high school & 12 & 57 \\
Senior high school & 1 & 5 \\
Diploma & 3 & 14 \\
Bachelor & & 5 \\
Employment Status & 1 & 14 \\
Private & 3 & 81 \\
Entrepreneur & 17 & 14 \\
Housewives & & 86 \\
Tenure & 3 & \\
5 years & 18 & \\
> 5years & & \\
\hline
\end{tabular}

b. Motivation of cadres in assessing growth and development with SDEID Table 2. Frequency distribution of cadre's motivation before and after training

\begin{tabular}{ccc}
\hline \multirow{2}{*}{ Motivation } & Before & After \\
\cline { 2 - 3 } & $\mathbf{N}$ & $\mathbf{N}$ \\
\hline High & 15 & 15 \\
Moderate & 6 & 6 \\
\hline
\end{tabular}


Journal of Maternal and Child Health (2019), 4(5): 351-357

https://doi.org/10.26911/thejmch.2019.04.05.08

c. Skills of cadres in assessing growth and development with SDEID Table 3. Frequency distribution of cadre's skills before and after training

\begin{tabular}{ccc}
\hline \multirow{2}{*}{ Skills } & Before & After \\
\cline { 2 - 3 } & $\mathbf{N}$ & $\mathbf{N}$ \\
Skilled & $\mathbf{0}$ & 7 \\
Quite Skilled & 0 & 11 \\
Less Skilled & 21 & 3 \\
\hline
\end{tabular}

Table 4. The Average Table of Pre Test and Posttest of Motivation and Skills

\begin{tabular}{lccccc}
\hline & N & Minimum & Maximum & Mean & SD \\
\hline Motivation pre-training & 21 & 56 & 71 & 64.62 & 4.95 \\
Skill pre-training & 21 & 0 & 21 & 11.00 & 5.24 \\
Motivation post-training & 21 & 53 & 72 & 63.62 & 5.17 \\
Skill post-training & 21 & 21 & 40 & 29.71 & 6.52 \\
\hline
\end{tabular}

\section{Bivariate Analysis}

Table 5. Difference of motivation between before and after training

\begin{tabular}{llccc}
\hline Motivation & N & Mean & SD & p \\
\hline Pre-training & 21 & 64.62 & 4.95 & 0.526 \\
Post-training & 21 & 63.62 & 5.17 & \\
\hline
\end{tabular}

Table 6. Difference of motivation between before and after training

\begin{tabular}{llccc}
\hline Skill & N & Mean & SD & p \\
\hline Pre-training & 21 & 11.00 & 5.24 & $<0.001$ \\
Post-training & 21 & 29.71 & 6.52 & \\
\hline
\end{tabular}

Table 5 showed the difference of motivation level before and after training among cadres. Table 5 showed that there was no difference motivation before (mean=64.62; $\mathrm{SD}=4.95)$ and after (mean= 63.62; $\mathrm{SD}=5.17)$ training, but it was statistically non-significant $(\mathrm{p}=0.526)$.

Table 6 showed the difference of skill level before and after training among cadres. Table 6 showed that skill after (mean= 29.71; $\mathrm{SD}=6.52)$ was higher than before training (mean $=11.00 ; \mathrm{SD}=5.24$ ) and it was statistically significant $(\mathrm{p}<0.001)$.

\section{DISCUSSION \\ 1. The effect of SDEID training on cadre's motivation}

The results of this study found that there was no difference motivation before (mean $=64.62 ; \mathrm{SD}=4.95)$ and after (mean=
63.62; $\mathrm{SD}=5.17)$ training, but it was statistically non-significant $(\mathrm{p}=0.526)$.

Based on the results, as many as $29 \%$ cadres were at age 47-54 years. There are no provisions regarding the age limit of being a cadre. Commonly, cadres are housewives or elderly. It decreases cadres' performance and skill because the older age, the lower physical skills. Therefore, cadres who were at age $\geq 50$ years old need regeneration with cadres aged $\leq 35$ years old (Wida, 2013). This was in accordance with Wahid et al. (2006), which stated that productivity decreased with increasing age. It was because physical skills such as speed, flexibility, strength, and coordination decreased with age. In an institution, employees who have worked for a long time in a system mean that they were getting older, can experience increased produc- 
tivity because of experience and wiser in making decisions.

The results of this study showed that the latest education of cadres was mostly senior high school (57\%). Education can change behavior, in addition, it was a tool that accelerated the decision making, in an effort to improve behavior so that people can continue to change. The level of formal education was the basic capital for someone to be able to understand and interact in the business and work competition. By having formal education, someone can be smart. The level of education, especially cadres in the village and in the city, would greatly influence the adoption of a new program which in this case the program for monitoring the growth and development of toddlers.

A mother especially a cadre with high level of education would try to find information in order to improve their knowledge and skills, especially in monitoring children's development. Low maternal education was a risk factor for developmental delay in children. Because low education was thought to be linearly related to the lack of knowledge and skills of cadres in stimulating child development (Haryanti, 2016). Therefore, cadres who have a higher level of education would help someone, especially cadres, to receive a new program and innovation in society. With a higher level of education, it would help someone, especially cadres, to accept a change. The high level of education was expected to make the ways of thinking to be more rational so that cadres would be more focused in participating in growth monitoring programs and able to assess growth itself, in order to increase public knowledge, especially mothers of infants and early detection of toddler growth and development.

Based on the results of the study on employment status, 17 cadres $(81 \%)$ was a housewife. A posyandu cadre should not have a permanent job so that there was plenty of free time to carry out their role as a posyandu cadre (Saifullah, 2011).

There were 18 people (86\%) who have working period for more than 5 years as a Posyandu cadre. According to Sutiani et al. (2014), the results of the study stated that $75 \%$ of new cadres were less skilled cadres, while $46 \%$ of old cadres were skilled in monitoring infant and toddler growth at the posyandu. This can be affected because older cadres have more experience and knowledge than new cadres. Therefore, training with practice methods or stimulation can be an option as an effort to improve the skills of new cadres and review information for the old cadres.

\section{The effect of SDEID training on cadre's skill}

The results of this study found that skill after (mean= 29.71; $\mathrm{SD}=6.52$ ) was higher than before training (mean=11.00; $\mathrm{SD}=$ 5.24) and it was statistically significant $(\mathrm{p}<0.001)$.

The training obtained was about monitoring and evaluating stimulation detection and early childhood development intervention. However, many posyandu cadres stated that after recieving the training, cadres did not conduct SDEID assessments during the posyandu due to many factors including many cadres who did not understand how to interpret the results of monitoring growth, too much children, difficult to handle fussy infants and children, the time of assessment process was too long, lack of assistance from health personnels and posyandu facilities that were less complete to support the process of monitoring and evaluating the growth of infants and toddlers.

One of the appropriate training methods for cadres was group dynamics. In group dynamics method, there was fami- 
liarity with group members, material, practice and games, so it was expected that cadres in training with group dynamics methods did not cause boredom and fatigue. Group dynamics method was a method and process that aimed to improve the values of group collaboration. This mean that the methods and processes of group dynamics tried to grow and build groups, which originally consisted of a collection of individuals who did not know each other, became a group unity with one goal, one norm and one way to achieve a mutually agreed effort. The training that has been attended by toddlers' posyandu cadres with group dynamics methods has enormous benefits, namely forming mutually beneficial cooperation, facilitating all work and creating a democratic climate in people's lives.

After the training, the skills of the cadre were quite good. Cadres were able to provide an interpretation of the growth and development of toddlers according to what has been obtained during the training.

According to a study by Munfarida (2012), $67.5 \%$ of cadres were still less skilled. While the factors that can influence the cadre's skills were parity, education, employment, working period as a cadre, and knowledge. Based on study by Irma (2013), there were $54.1 \%$ of unskilled cadres in the Hamparan Perak community health center. While the factor that affect the cadre's skills in carrying out their tasks was knowledge so that continuous training and coaching was needed so that the cadre's skills become good and the performance of the posyandu also increased.

\section{ACKNOWLEDGEMENT}

The author would like to thank the Ministry of Research and Technology and LLDIKTI Region VI of Central Java which has funded and supported this study.

\section{REFERENCE}

Haryanti RS (2016). Pengaruh pendidikan, pekerjaa ibu, pendapatan keluarga dan berat badan lahir terhadap perkembangan anak prasekolah di TK Aisyiyah III Kadipiro. Tesis. Universitas Sebelas Maret Surakarta.

Irma $J$ (2013). Pengaruh karakteristik dan pembinaan kader dalam pelaksanaan kegiatan posyandu terhadap keterampilan kader di wilayah kerja Puskesmas Hamparan Perak tahun 2013. Tesis. Universitas Sumatera Utara: Program Studi S2 Ilmu Kesehatan Masyarakat

Kemenkes RI (2010). Pedoman pelaksanaan stimulasi deteksi dan intervensi dini tumbuh kembang anak di tingkat pelayanan kesehatan dasar. Jakarta

Munfarida S (2012). Faktor yang berhubungan dengan tingkat pengetahuan dan keterampilan kader posyandu. Skripsi. Surabaya: Fakultas Kesehatan Masyarakat Universitas Airlangga

Rosita, Norazizah (2015). Studi deskriptif perkembangan balita usia 12-24 bulan dengan metode DDST II di Desa Pancur Kecamatan Mayong Kabupaten Jepara. Jurnal Kesehatan dan Budaya. 8(1).

Rosphita A (2007). Faktor-faktor yang berhubungan dengan ketrampilan kader dalam menginterpretasikan hasil penimbangan $(\mathrm{N}$ dan $\mathrm{T}$ ) dalam KMS di Puskesmas Baumata Kabupaten Kupang. Naskah Publikasi. Skripsi. https://muslimpinang.files.wordpress .com/2010/10/agustina-rospitapublikasi.pdf di akses pada tanggal 9 Agustus 2018

Saifullah (2011). Pengaruh karakteristik kader posyandu terhadap penimbangan balita di Kecamatn Kembang Tanjung Kabupaten Pidie Provinsi Aceh. Tesis. Medan: Program Studi S2 Ilmu 
Kesehatan Masyarakat Universitas Sumatera Utara

Sianturi, Tambunan, Ningsih (2013). Peningkatan kemampuan kader kesehatan dalam melakukan deteksi tumbuh kembang balita melalui pelatihan. dalam http://www.ejurnal.poltekkesjakarta.ac.id.

Sugiyono (2011). Metode Penelitian Kuantitatif Kualitatif dan R\&D. Bandung: Alfabeta.

Wida N (2013). Hubungan tingkat pengetahuan, pendidikan, usia dan lama menjadi kader posyandu dengan kua- litas laporan bulanan data kegiatan posyandu. Naskah Publikasi Ilmiah. http://eprints.ums.ac.id/27723/16/O2._NASKAH_PUBLIKASI.pdf di akses pada tanggal 10 Agustus 2018.

Wahid I, et al. (2006). Ilmu Keperawatan Komunitas. Jakarta: CV Sagung Seto

Zainiah N (2014). Hubungan frekuensi pelatihan yang diikuti kader dengan tingkat ketrampilan kader dalam pelayanan posyandu balita di Desa Nogotirto Gamping Sleman Yogyakarta dalam http://www.opac.say.id. diakses tanggal 17 Juni 2017. 